\title{
Public Perceptions of the Blasphemy Case of Muhammad Kace on Social Media
}

\author{
Nur Jannah $^{1^{*}}$, Agus Machfud Fauzi ${ }^{2}$ \\ ${ }^{1}$ Universitas Negeri Surabaya \\ ${ }^{2}$ Universitas Negeri Surabaya \\ *Corresponding Author. Email: nurjannah.20061@mhs.unesa.ac.id
}

\begin{abstract}
Case of blasphemy that recently occurred started when a YouTuber with the channel name Muhammad Kace streamed with words that insulted the Prophet Muhammad SAW. Thus making Muhammad Kace a defendant in the matter of blasphemy against religion and society. The purpose of this study was to look at the public's perception of the case of blasphemy by Muhammad Kace on social media. Descriptive qualitative approach that will be used in this study. Data collection techniques using interviews, the results of the interviews will be collected then analyzed and drawn into conclusions. In this study, the perspective that will be used is the theory of Max Weber's Actions of Rationality. The results of this study indicate that it is generally known that the perception of some people that the case of blasphemy of Muhammad Kace causes unrest. Besides that, some people have the opinion that everything is left to the Criminal Investigation Department and does not interfere in this matter, however, there are also those who report and comment on social media to support the detention of Muhammad Kace.
\end{abstract}

Keywords: Blasphemy, Perception, Muhammad kace, Society

\section{INTRODUCTION}

Society is unbreakable from mixing different social media apps. People can access social media from time to time. People use social media to communicate and seek positive information (Sumadi, 2016). This is certainly a positive value for the community so that people can improve their literacy. The existence of social media is used by Islamic religious leaders as advice for preaching by inviting others to do good. So that religious leaders or scholars do not need to travel on foot to spread the religion of Islam. Da'wah using social media is believed to be more effective and the results will be seen by an

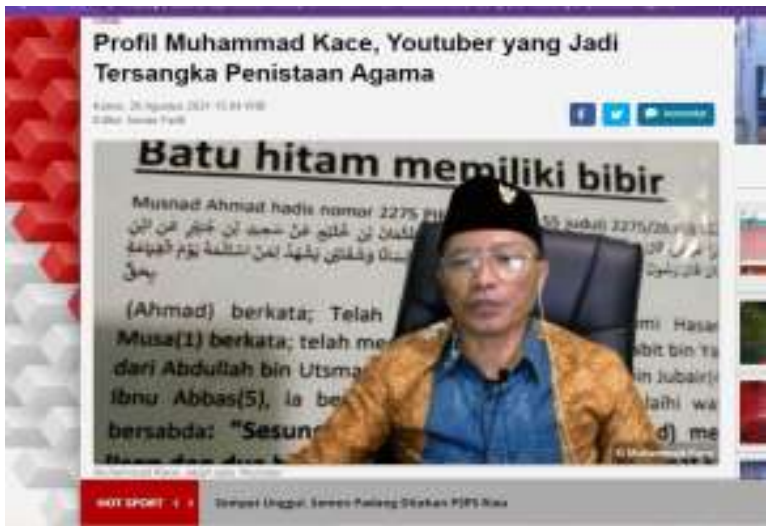

Figure 1 Muhammad Kace is a Suspect unlimited number of people (Zilli, 2018). So religion and social media have a significant relationship. 
Islam is one of the religions with the most adherents in Indonesia. Islam is often inseparable from various problems related to belief although, Islam is known for its peace and beauty. One of the cases that often occurs is the case of insulting religion. In Indonesia, there are often cases of blasphemy against religion, as seen in the picture above is an example of a blasphemy case that recently occurred in a case of blasphemy committed by a YouTuber Muhammad Kace. The case of Muhammad Kace is related to insulting Islam and the Prophet Muhammad.

The statement from Muhammad Kace that was made during a live streaming on social media made Muslims in Indonesia angry and felt that Islam had been insulted by the words "Muhammad became Jesus". Muhammad Kace also invited Muslims to leave the teachings of Islam. (https://bit.ly/3CnbZ1h accessed on

3 September 2021). Muhammad Kace often creates Youtube content containing SARA, in a content entitled "The Yellow Book is Confusing" he says "because Muhammad Bin Abdullah is a follower of the jinn".

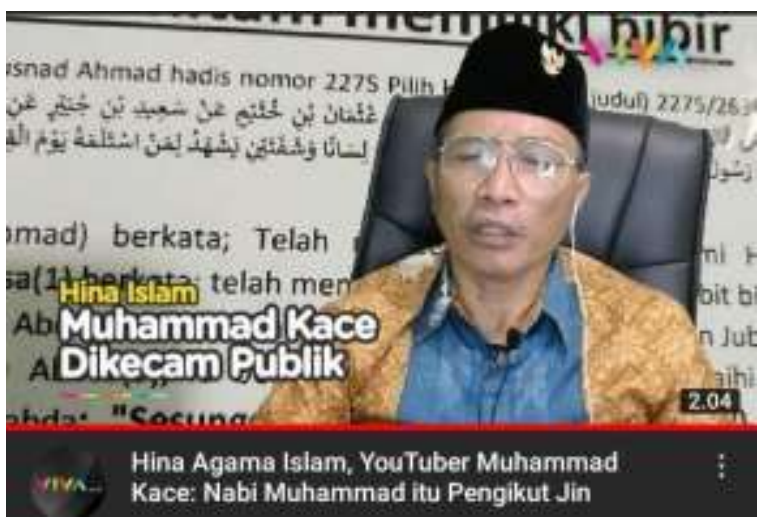

Figure 2. Muhammad Kace Publicly Criticized

What Muhammad Kace did got criticism from various circles of society, as seen above Muhammad Kace was criticized by the public. Even the MUI strongly condemns what Kace said and is worried that the public will be angry if this case is not immediately prosecuted. Then the Bareskrim Polri immediately carried out an investigation because it received various reports from the public to immediately follow up on the Muhammad Kace case. The Islamic community does not forgive what Muhammad Kace did so people flock to social media by supporting the arrest of Muhammad Kace. Actually Muhammad Kace has been reported in April 2021, however, it has not been processed.

According to the background of the problem above, this observation will discuss what the public's perception of the blasphemy case by Muhammad Kace is. The final results of this study are needed to be able to share facts with the public and workers throughout Indonesia regarding the public perception of the blasphemy case by Muhammad Kace on social media.

Perception is a person's treatment system, such as giving comments, meanings, and reflections on what is cared for, observed, and seen in the form of actions, comments, and behavior. Yuwawi (2017) says that perception is a person's comment on something that starts from the eyes that form the urge to act on something. Thus, self-perception is more indicative of attitudes and opinions towards what a person receives at that time.

Max Weber's theory of rationality will be used in this research. According to Weber's theory of rationality, people's perception of Muhammad Kace's case of insulting religion can be seen from the act of value rationality. Value rationality will see people's actions that are directed by faith enough to know the values of ethical, religious, aesthetic, and other forms of behavior. There is a previous research by Ivan Tandayu with the title Public Opinion on the Coverage of Blasphemy of Islam by Ahok in Television Media. The article discusses several public opinions regarding Ahok's reporting of religious insults on social media. In contrast to this study, which reviews the public's perception of the blasphemy case by Muhammad Kace. 


\section{METHODS}

Descriptive qualitative research used in this study. Qualitative research aims to obtain a general understanding of social facts from various participant perspectives (Ruslan, 2010). Therefore, this research will look for facts in society from various perceptions regarding blasphemy that is happening now. According to Sugiyono (2013) the research method is observation carried out in order to understand the meaning of factors without combining or comparing one factor to another. So, qualitative research is an assessment that seeks social reality from various perceptions in the form of data, then the data is described and a conclusion is drawn. In this qualitative research, it is important to emphasize the closeness to the community and the conditions of the research field. This is done in order to get a clear understanding of reality and real life situations.

The object of the research is the community. The community will take 6 people as informants. Data collection techniques for this study using interviews and observations. Data collection techniques are considered an important factor for the success of a study (Permadi, 2018). Therefore, the research also uses data collection techniques. Types and sources of data used there are sources, namely primary and secondary. Primary sources are data taken directly in the form of verbal while secondary sources are data taken from supporting primary data (Erawan, 2018). The primary data in this study were taken from the results of interviews by the community to obtain the information needed in this research. The secondary data of this research are articles, news on the internet, and several supporting books.

\section{RESULT AND ANALYSIS}

The issue of the blasphemy case of Muhammad Kace has successfully attracted the attention of the Indonesian people. By itself the news of Muhammad Kace reached the community, it was evident from the public's response to the mention of this case. First, $A I$ revealed that he knew about the blasphemy case of Muhammad Kace through social media. He explained that it was true that the blasphemy case of Muhammad Kace needed attention from the government.

"Yes, I know the content he created. The content seems to have insulted the religion of Islam, cases like that have happened a lot, yes, even from the upper classes it has been proven that they have done it."

But for Al the case of blasphemy is not something that can be taken lightly, there needs to be action from the government.

"It's a matter of insulting religion, so we can't take this problem lightly, it still has to be investigated. It is clear that if it is not addressed immediately, it will happen again. His insults were also carried out on social media, he was afraid that someone would follow his teachings so he could be brought to justice soon. there is also a law regarding blasphemy. So the government needs to address this."

Furthermore, according to $A 2$, the blasphemy case of Muhammad Kace is a serious matter.

"I initially knew from the news on TV about the Muhammad Kace case. Yes, because this case of insulting religion is a serious matter that needs to be resolved, so that it does not happen again and so that the perpetrators are ignored". 
Then there is the A3 informant, according to him, this really needs to be investigated because it is a serious problem and even supports other people to comment on social media.

"The issue of blasphemy cannot be ignored because it is a serious problem in my opinion. I also support if anyone comments on social media about the arrest of Muhammad Kace or resistance like the previous case. because I think if people are aggressively commenting on social media, of course they will get a response from the government so that the government can quickly solve this problem."

Switching to $A 4$ for him, the blasphemy case must be investigated quickly so that Muhammad Kace can be punished.

"Maybe an investigation will be carried out soon, because this problem has brought the name of religion, so don't let this case be repeated many times later. Kace will also get his punishment according to what he did."

Then $A 5$, he does not interfere in the matter, but hopes that Kace gets the punishment he deserves as well.

"In my opinion, this case is quite serious, we just follow the flow of the case, it must have been handled by the authorities. I support the arrest but don't interfere too much with it. I also hope to get the appropriate punishment."

A6 commented what Kace was doing, saddened by his condition.
"I'm quite sad to see what Kace did he shouldn't have done. it's also possible that because of the inappropriate attitude of the same case, other similar cases will be repeated."

Various views from the public regarding the case of blasphemy Muhammad Kace. Can be compared from one informant to another. For $A l$ to respond to the blasphemy case by explaining that the blasphemy case committed by Muhammad Kace was the same as previous cases that had occurred in Indonesia. clearly what Muhammad Kace said was insulting to religion. A2 has also seen previous cases so cases like this need to be dealt with as soon as possible. The government also explained that the blasphemy case should not be taken lightly by the government because Muhammad Kace had acted beyond reason by insulting Islam, with insults being broadcast on social media, allowing anyone to follow his teachings, so they need to be handled by the authorities. Indonesia itself has regulated blasphemy in a law so that Muhammad Kace needs to be brought to justice.

This is different fromperception $A 2$ 's which states that he has seen the content created by Muhammad Kace. According to him, what Kace has done has insulted religion and has become a serious matter for Indonesia, it is necessary to take action so that blasphemy cases do not occur repeatedly, it can provide a deterrent effect for perpetrators so that blasphemy cases may not happen again in the future. There are interesting things fromopinion $A 3$ 's, namely his attitude and response to the case of Muhammad Kace's blasphemy by supporting the Indonesian people to comment on Muhammad Kace to the government, even fighting might be possible to bring Muhammad Kace to justice. According to him, if there is an action of resistance or commentary action on social media, it 
will get a faster response from the government, of course by looking at previous cases of blasphemy.

perception $A 4$ 's states that he hopes that the blasphemy case committed by Muhammad Kace will be investigated immediately. This is done so that in the future the same case does not happen again. In contrast to informant A5, who is not too involved in blasphemy matters, he believes that what Muhammad Kace did is the government's responsibility to handle cases of blasphemy. but he strongly supports that Muhammad Kace was arrested and punished according to his actions. A6 also gave his view that what Muhammad Kace did was because the previous case was not handled properly so that the same case was repeated. Regarding interviews that have been carried out by all pro informants to the Muhammad Kace case, it means that the community agrees that Muhammad Kace will be processed through legal channels.

Muhammad Kace's criticism was not only addressed to the village community, but also to several comments on social media, such as Instagram, Youtube, Twitter, and others. People flocked to say or blaspheme Muhammad Kace. The response of the Indonesian people to Muhammad Kace is very varied.

\section{Alhamdulillah penistaan agama di tangkap} 象 船

Figure 3. Community Coments on Youtube

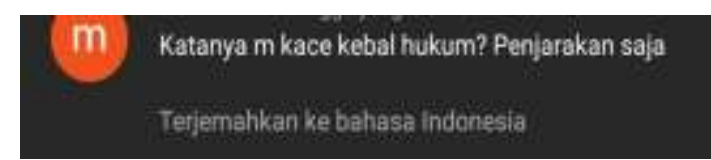

Figure 4. Community Coments on Youtube

Like the pictures above, which are quoted from Youtube comments, they both have the opinion to immediately imprison Kace so that he doesn't repeat his mistakes again. This means that the community is very supportive so that Kace is immediately processed by the law. In addition to the two comments, there are actually many more comments made by the public in the form of blasphemy, protests, and support for Muhammad Kace. The public's opinions or comments on social media are aimed at encouraging the government and law enforcement officials to immediately take legal proceedings against Muhammad Kace.

Humans always take action to achieve certain goals. According to Weber, the earth was created by social action. Social action is a step that humans do by being influenced by other people. This allows Weber to distinguish between societies by understanding why they act. Social action is divided into four, namely instrumental rational action, value-oriented rational action, traditional action, and affective action. Public perception of Muhammad Kace will be associated with social action according to Weber.

Various views and actions of the public regarding the blasphemy case of Muhammad kace on social media. Perceptions and actions taken are related to the value-oriented theory of rationality. What the community does is a form of belief and awareness of religious values. Values, ethics, and religion affect human behavior in life (Umanailo, 2008). it is evident from the statements of the informants, that the community responds according to the values they believe in because they are aware of the beliefs they live by getting blasphemy, finally the community gives their actions and views on this matter. The perception or response of the public regarding the Muhammad Kace case can also be related to affective actions, in which people are currently controlled by emotional feelings 
because of Kace's words that offend Islam. So, the actions taken by this community were not carefully planned so that the community responded spontaneously to the blasphemy incident of Muhammad Kace.

\section{CONCLUSION}

Based on the results of data collection from informants and then an analysis was carried out, it was known that the public's perception of the blasphemy case of Muhammad Kace on social media was that the community demanded the arrest and that Muhammad Kace was immediately prosecuted. The public also judged and criticized that Kace's words on his Youtube content were very negative things to look at and considered provocative to contain SARA. Public perception of blasphemy cases associated with Max Weber's social actions has a relationship. It can be seen through the actions of value-oriented rationality that people comment or argue because the community feels that what is being done can be useful because it is hoped that the government can immediately carry out legal proceedings.

This research is expected to be an implication for future research by further growing the case of insulting religion and describing it more broadly. The public is also expected to be able to filter news content by the media, especially regarding religion, so that it is hoped that Indonesia will create peace and mutual respect in religion. Religious leaders are also expected to be able to inform about religion correctly and according to existing teachings so as not to cause religious blasphemy.

\section{REFERENCES}

[1] Ahmad, MR (2018). Cases of Blasphemy/Defamation of Religion in Indonesia Perspective of the Elite Muhammadiyah Surabaya. Thesis

[2] Annazilli, H. (2018). Relations Between Religion and New Media. Syi'ar Scientific Journal, 18(2), 26.

[3] Anggraeni, Winda. 2013. “Tindakan Sosial Pemuka Agama Islam Terhadap Keberadaan Transgender (Studi Deskriptif Mengenai Tindakan Sosial Pemuka Agama Islam Terhadap Keberadaan Transgender di Kawasan Kota Surabaya, Jawa Timur.)

[4] Azhar, P. (2018). Blasphemy of Religion and Social Violence in Temanggung Regency in 2011. Scientific Journal of Sociology of Religion (Jisa), l(1), 81 .
[5] Fauzy, VR, Wibowo, JH, Romadhan, MI, \& Communication, I. (2017). Acceptance of Hoax News "Blame of Religion" through Social Media for UKMKI Untag Surabaya Students.

[6] Fitriyah dan Dzunuwanus Ghulam Manar, Anatomi Konflik Sosial Di Jawa Tengah: Studi Kasus Konflik Penistaan Agama Di Temanggung, 2012.

[7] Pangestu, PP (2021). INDONESIAN MUSLIM IDENTITY CONSTELLATION IN THE DIGITAL MEDIA: Labeling Arrogant Islam by Permadi Arya on Social Media. Al-Tahrir: Journal of Islamic Thought, 21(1), 55-71.

[8] Permadi, AY (2018). Communication Science Student Perception. EJournal of Communication Studies, 5961(3), 520-532.

[9] Sumadi, E. (2016). Da'wah and Social Media: Spreading Kindness Without Discrimination Journal of Islamic Broadcasting Communication, 4(1), 173-190.

[10] Umanailo, MCB (2019). Max Weber. 1-4.

[11] Yuwavi, D., \& Mustika Kartika Sari, M. (2017). Perceptions of Unesa Education Students About the Anti-Defamation Movement. Volumes 05, 441- 455. 